solution-for example, $0.5 \mu \mathrm{g} . / \mathrm{ml}$. It seems probable that the outstanding prophylactic effectiveness of silver nitrate compresses is due to the high concentration of silver ions present in the dressings for a short while after each replenishment of silver nitrate solution.

The tests on Ps. aeruginosa showed that the lowest concentration of silver ions associated with bactericidal action was considerably higher than that associated with bacteriostasis. This difference can probably be ascribed in part to the shorter exposure of bacteria in the tests for bactericidal action; it is possible, too, that a higher concentration of silver ions is required for killing than for inhibition of the bacteria.
REFERENCES

Cason, J. S., Jackson, D. M., Lowbury, E. J. L., and Ricketts, C. R

Fox., C. L., Rappole, B. W., and Stanford, W. (1969). Surgery, Gynecology and Obstetrics, 128, 1021.

Lawrence, J. C. (1959). British fournal of Pharmacology and Chemotherapy, 14, 168

Lawrence, J. C. (1970). Proceedings of International Symposium on Treatment of Burns. Amsterdam, Excerpta Medica. In press.

Lowbury, E. J. L., and Jackson, D. M. (1968). Lancet, 1, 654.

Lowbury, E. J. L., and Jackson, D. M. (1970). Injury, 1, 204.

MacMillan, B. G., Hill, E. O., and Altemeier, W. A. (1967). Archives of Surgery, 95, 472 .

Miles, A. A., Misra, S. S., and Irwin, J. O. (1938). Fournal of Hygiene,

Moyer, C. A32. Arentano, L., Gravens, D. L., Margraf, H. W., and Monafo, W. W. (1965). Archives of Surgery, 90, 812.

\title{
Study on the Effects of Tablet Colour in the Treatment of Anxiety States
}

\author{
KURT SCHAPIRA, ${ }^{*}$ M.D., D.P.M. ; H. A. MCCLELLAND, $†$ M.R.C.P., D.P.M. \\ N. R. GRIFFITHS, $\ddagger$ M.B., D.P.M. ; D. J. NEWELL, $\$ M.A., PH.D., F.S.S.
}

\begin{abstract}
Cummary: Forty-eight patients with anxiety states were $\checkmark$ treated with oxazepam (Serenid-D), which was administered in tablets of three different colours-red, yellow, and green. Every patient received one week's treatment with each colour, according to a random programme. A latin square design was used to ensure complete balance between the colours and between the weeks. The patients' symptoms were categorized and then assessed by both weekly physicians' ratings and daily self-rating, which showed close agreement. Colour preference was shown on both these scales in that symptoms of anxiety were most improved with green, whereas depressive symptoms appeared to respond best to yellow. Such colour preferences, however, did not reach levels of statistical significance, except for phobias as rated on the physicians' assessment.
\end{abstract}

The results indicate that colour may play a part in the response to a drug.

\section{Introduction}

That the response to drug treatment does not merely reflect the chemical effect of the drug used has long been appreciated as an important feature in medical practice. The way in which a therapist preser ts treatment to the patient is important in this context, and there is an extensive literature on the therapeutic effects of chemically inert substances-the so-called placebo effect as discussed by Beecher (1955) and Shapiro (1960) among others. In psychiatric practice particularly, the halo effects of such factors may be of considerable importance.

The present investigation aims to examine the possible role of tablet colour in the drug treatment of patients with anxiety states, an aspect of drug treatment that does not seem to have been the subject of previous scientific inquiry. Furthermore, the study has been so designed as to permit comparison of patients' self-rating assessments with those made by the physicians.

\section{Method}

The drug used in this study was oxazepam (Serenid-D), a member of the benzodiazepine group shown by Le Gassicke

\footnotetext{
* Lecturer, Department of Psychological Medicine, University of Newcastle upon Tyne.

† Consultant Psychiatrist, St. Nicholas Hospital, Newcastle upon Tyne. Newcastle General Hospital, Newcastle upon Tyne.

‡ Formerly Senior Registrar, Department of Psychological Medicine, Newcastle General Hospital, Newcastle upon Tyne.

$\checkmark$ Professor of Medical Statistics. University of Newcastle upon Tyne.
}

and McPherson (1965) and Beber (1965) to be an effective anxiolytic agent. The dosage given was $15 \mathrm{mg}$. t.d.s. and the tablets were presented as plain (non-scored) coloured nonsugar-coated tablets. The three colours used were green, yellow, and red, and each patient received a week's treatment with each colour in a random order.

\section{Patient Group}

The 48 patients included in the trial were attending psychiatric outpatient clinics and had been diagnosed as suffering from anxiety states. Since anxiety and depressive symptoms commonly occur together, only those patients in whom anxiety was the primary affective disturbance were included. All patients had normal colour vision when tested by means of isochromatic plates (Ishihara test). In those who had been on previous medication all drugs were discontinued at least two days before the trial was begun, and for one week in respect of phenothiazins or antidepressants. Oxazepam was the only drug taken by the patients during the trial period, except for hypnotics, which were continued if they had previously been prescribed and had been beneficial.

First Interview.-This comprised a clinical assessment of the patient followed by a decision on suitability for inclusion in the trial.

Information Given to Patients.-The patients were told that the tablets which they would receive had been found to help others with symptoms similar to their own, but that the object of the trial was to determine which of the three kinds of tablets was most effective in relieving their symptoms. It was also stressed at the beginning of the trial that to keep the physician's assessment as unbiased as possible the patients should not refer to the colour of the tablets.

The evaluation of the patients' response during each week of treatment was based on a self-rating scale and on a physician's rating scale. The self-rating scale adopted was that used by Lader and Wing (1966).

\section{Self-Rating}

A completed self-rating form in which the patient's symptoms were recorded in his own words-for example, "feeling afraid," "palpitations,"-is shown (Fig. 1). Furthermore, to ensure that no relevant symptoms of anxiety had been missed systematic inquiry was made relating to the following four main groups of symptoms: 
(1) Psychic Anxiety.-Including symptoms such as "feelings of fear," "feeling anxious," "as though something is going to happen."

(2) Somatic Symptoms.-Such as "palpitations," "shakiness," or "dryness of the mouth."

(3) Phobias.-These include any kind of irrational fear related to a specific situation or object. In our group of patients these were mainly agoraphobias.

(4) Depressive Symptoms.--Such as feeling "low in spirits," "sadness of mood"; these were not present in all patients and when present were secondary to the anxiety and of only mild or moderate severity.

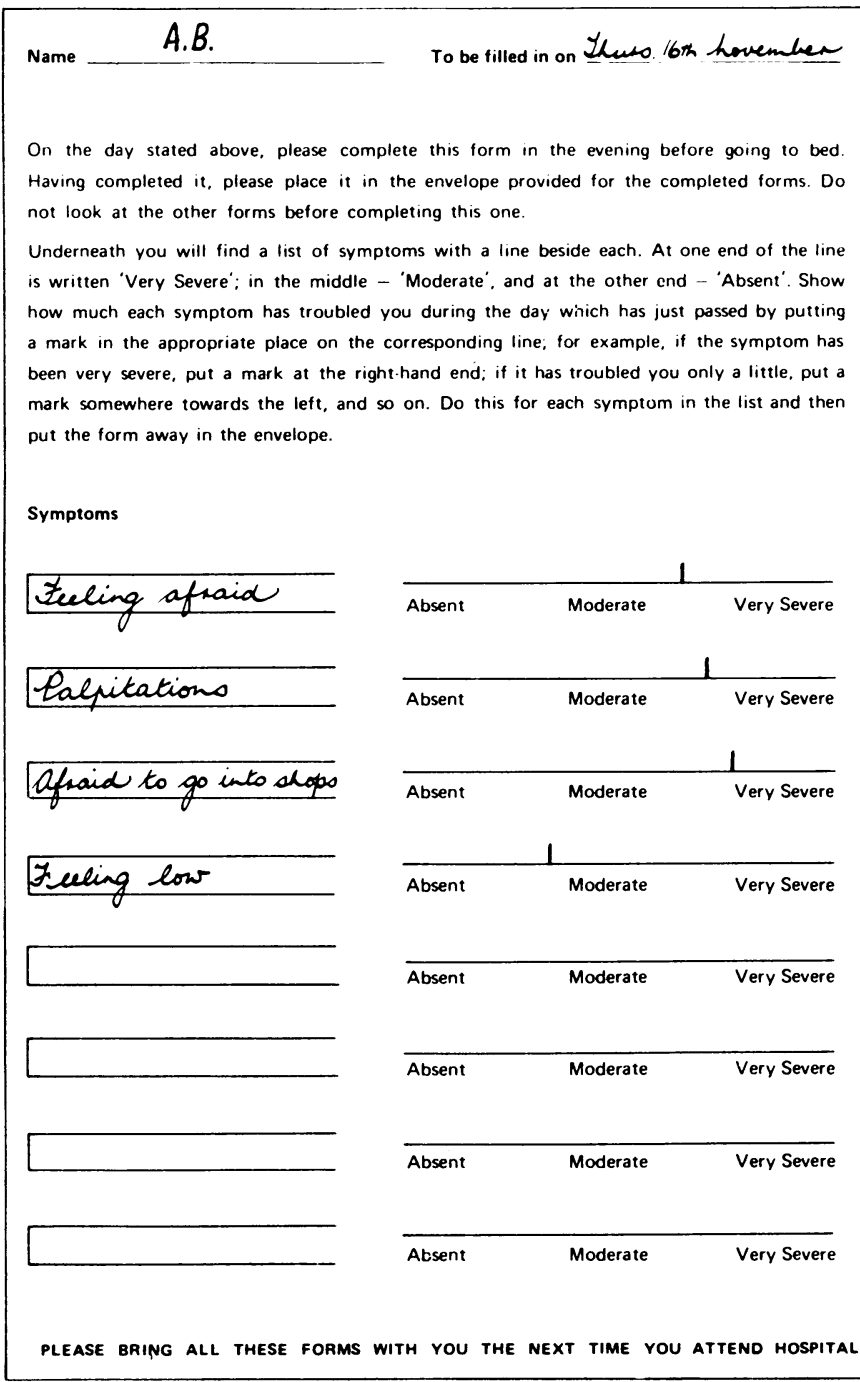

FIG. 1.-Self-rating scale.

At the end of the first interview the patient was asked to represent the severity of each of his symptoms by a vertical mark along the appropriate $10-\mathrm{cm}$. horizontal scale. This first rating was taken as a baseline representing the clinical state before the trial. The method of marking was carefully explained to each patient, who was then issued with seven self-rating forms and asked to complete one form every evening for the following week (see Fig. 1). The subjective degree of severity of each symptom during each day was thus recorded and the patient sealed his self-rating form in an envelope, precluding comparison from day to day. In addition to the verbal instructions given to the patients, written instructions on the scoring were included on the self-rating form. For each week of treatment a patient's self-rating score for a group of symptoms was defined as the mean $(\mathrm{cm}$.) of the seven daily scores for each of his symptoms in the group.

\section{Physician's Rating}

At the first interview an assessment of the patient's symptoms was made by the physician, the symptoms being allocated to one of the four main categories already described. An example of a completed form to record these is shown in Fig. 2. The physician's subsequent weekly assessment was made on a nine-point scale for each symptom, ranging from -4 (much worse) to +4 (much better). The scoring was based on a comparison of each of the symptoms during the preceding week with that of the pretrial state. An overall assessment of change from the pretrial state on a nine-point scale was also made.

\begin{tabular}{|c|c|c|c|c|c|c|}
\hline \multicolumn{7}{|c|}{ SERENID-D (Oxazepam) COLOUR TRIAL } \\
\hline \multirow{2}{*}{\multicolumn{7}{|c|}{$\begin{array}{l}\text { Hospital Number : } \frac{632765}{\text { A.B. }} \\
\text { Name: } \frac{\text { Age: } 22}{\text { A.B. Sex }: F}\end{array}$}} \\
\hline & & & & & & \\
\hline \multicolumn{7}{|c|}{ Diagnosis: ANXIETY NEUROSIS } \\
\hline \multicolumn{7}{|c|}{ First or recurrent illness: FIRST } \\
\hline \\
\hline \multirow{3}{*}{\multicolumn{7}{|c|}{$\begin{array}{l}\text { Duration of present illness: } 2 \text { YEARS } \\
\text { Previous treatment and response: } \text { TRYPTIZOL } 25 \mathrm{mgms} \text { b. } \\
\text { Discontinuation of previous treatmert: } 5 \text { WEEKS }\end{array}$}} \\
\hline & & & & & & \\
\hline \\
\hline & & & & & & \\
\hline \multicolumn{7}{|c|}{ Date of starting trial: $17 \mathrm{~h}$ NOYEMBER 1968} \\
\hline \multicolumn{7}{|c|}{ ASSESSMENT OF SYMPTOMS } \\
\hline \multirow{9}{*}{$\begin{array}{l}\text { Psychic- } \\
\text { Anxiety }\end{array}$} & & & $\begin{array}{l}\text { Pretrial } \\
\text { Sovority }\end{array}$ & $\begin{array}{l}\text { End of } \\
\text { 1st wook }\end{array}$ & $\begin{array}{l}\text { End of } \\
\text { 2nd wook }\end{array}$ & $\begin{array}{l}\text { End of } \\
\text { 3rd woek }\end{array}$ \\
\hline & Overall & & moderate & +2 & +1 & +3 \\
\hline & Worry & & moderate & +4 & +2 & +3 \\
\hline & Tension & & moderate & +2 & +2 & +1 \\
\hline & Irritability & & moderate & +2 & +2 & +1 \\
\hline & $\begin{array}{l}\text { Somatic sym } \\
\text { (specify) }\end{array}$ & nptoms & $\begin{array}{l}\text { moderate } \\
\text { palpitations }\end{array}$ & -3 & -4 & +4 \\
\hline & Phobias Ispe & cify) & $\frac{\text { moderate, }}{5 \text { hen }}$ & +4 & +4 & +1 \\
\hline & Depression & & mild. & -4 & -3 & -2 \\
\hline & $\begin{array}{l}\text { Side effects } \\
\text { (specify) }\end{array}$ & & & $\begin{array}{l}\text { sleepy, } \\
\text { unsteady }\end{array}$ & nightmeres & nil \\
\hline & \multirow[t]{2}{*}{$\begin{array}{l}\text { Severity: } \\
\text { Response: }\end{array}$} & \multicolumn{4}{|c|}{$\begin{array}{l}\text { Rate as Severe, Moderate, Mild, Nil. } \\
\text { COMPARED WITH PRETRIAL SEVERITY }\end{array}$} & \\
\hline & & \multicolumn{3}{|c|}{$\begin{array}{l}-4=\text { much worse } \\
+4=\text { much better }\end{array}$} & & \\
\hline & Initials & K.S. & & & & \\
\hline
\end{tabular}

FIG. 2.-Physician's rating scale.

At the second interview (end of the first week of treatment) the completed self-rating forms for the first week were collected and a further set including the same symptoms were issued to the patient. This procedure was repeated until the patient had received a three-week course of treatment.

\section{Allocation of Treatments and Dispensing Procedure}

A randomization programme was incorporated into the dispensing record sheet providing the colour sequence for each patient, who received a week's treatment on each colour. The physician making the weekly assessment was unaware of the code, and hence the trial was double-blind and crossover in design. Strictly speaking, the application of the term "double-blind" requires some modification, as the patients 
were unaware of the drug they were having but aware of its colour, whereas the physicians were aware of the nature of the drug but not of the colour sequence. A latin square design was used to ensure complete balance between the colours and between the weeks.

A coloured tab attached to each bottle of tablets issued was removed and placed on the dispensing record sheet at the time of dispensing as a check on the colour issued. A further precaution to ensure that the patients discontinued each colour at the end of the week was taken; each bottle had to be returned to the pharmacist before a new supply was issued, and since it had originally contained 28 tablets-that is, seven in excess of those required-the remaining tablets were counted and recorded, thus serving as a check on the number of tablets taken by the patients during the trial period.

\section{Results}

Of the 48 patients included in the trial 27 were women and 21 men, the mean age being 34.0 years. Two patients originally included failed to complete the trial and were replaced by a further two to complete the balanced latin square design.

Thirty-one patients were suffering from their first psychiatric illness, whereas 17 had a history of previous psychiatric disability. The duration of illness was less than three months in three patients, 3 to 12 months in 20, and one year in 25 . There was no sex difference as regards duration of illness.

All 48 patients scored themselves for symptoms of psychic anxiety as well as for somatic symptoms, whereas only 17 patients had phobic symptoms and 28 depressive symptoms. If a patient had more than one symptom belonging to one symptom group-for example, palpitations and dryness of the mouth (group 2)-the mean of the combined scores was used. An analysis of the mean scores on the self-rating scales for each of the symptom groups was carried out to determine any differences between the three weeks of treatment. No significant difference between the first, second, and third weeks was found. This finding implies the lack of any cumulative effect of the drug producing a gradual improvement in a linear manner with the maximal effect in the third week. There is also an absence of any apparent psychological effects as a result of starting a new form of treatment which might have produced a pronounced improvement in the first week as compared with subsequent weeks of treatment. These observations make it clear that any significant differences found in the group as a whole must be due to colour.

In view of the relatively small number of patients with shobias the balanced statistical analysis of complete latin iquares could not be carried out for this symptom. An analysis If variance with unequal subclass numbers, as described oy Rao (1952): was, however, carried out. This showed that there was no significant difference between weeks for this symptom. The same is true for the depressive symptoms.

Comparison of pretrial scores with the scores of the final week are given in Table I. This shows a significant improvement in symptoms of psychic anxiety over the trial period $(\mathrm{P}<0.01)$.

TABLE I.-Comparison of Final Scores with Pretrial Scores

\begin{tabular}{|c|c|c|c|c|}
\hline \multirow[b]{2}{*}{ Symptom Group } & \multicolumn{4}{|c|}{ Self-rating Scores } \\
\hline & $\begin{array}{l}\text { Pretrial } \\
\text { Score }\end{array}$ & $\begin{array}{l}\text { Mean Reduction } \\
\text { from Pretrial } \\
\text { Score }\end{array}$ & $\begin{array}{c}\text { Standard Error } \\
\text { of Reduction }\end{array}$ & $\begin{array}{c}\text { Significance } \\
\text { Level }\end{array}$ \\
\hline $\begin{array}{l}\text { Psychic anxiety. } \\
\text { Somatic }\end{array}$ & $4 \cdot 7$ & 1.05 & $0 \cdot 35$ & $P<0.01$ \\
\hline $\begin{array}{ll}\text { symptoms } & \ldots \\
\text { Phobias . } & \ldots \\
\text { Depression } & \ldots\end{array}$ & $\begin{array}{l}3 \cdot 0 \\
4 \cdot 5 \\
4 \cdot 0\end{array}$ & $\begin{array}{r}-0.15 \\
1 \cdot 18 \\
0 \cdot 25\end{array}$ & $\begin{array}{l}0.32 \\
0.62 \\
0.29\end{array}$ & $\begin{array}{l}\text { N.S. } \\
\text { N.S. } \\
\text { N.S. }\end{array}$ \\
\hline
\end{tabular}

The mean scores on the self-rating scales in relation to colour are shown in Table II. Low scores represent good responses and high scores adverse responses. Though the differences between colours do not reach statistical significance certain trends are observed. Thus all the groups comprising symptoms of anxiety had the lowest score-that is, the best response-when the patients took the active preparation in a green colour, whereas with depressive symptoms the colour preference appeared to be different in that yellow was the preferred colour, green and red occupying second and third places respectively. In contrast it will be seen that yellow appeared to be the least preferred colour as regards symptoms of anxiety.

The mean scores on the physicians' ratings for period sequence are shown in Table III. There are no significant differences between the three periods of treatment for any of the symptom groups. There is, however, a highly significant improvement in the overall assessment and in each symptom group of anxiety in the third week $(P<0.001$ except for phobias, where with smaller numbers $P<0.01$ ). The physicians' ratings for colour are shown in Table IV, and the findings closely parallel those obtained from the patient's self-rating It will be seen that colour preference for phobic symptoms reaches a significant level-F=6.05, $P<001$-with green preferred (the analysis is shown in Table V). Symptoms of psychic anxiety show a trend in the same direction, whereas depressive symptoms again tend to show more improvement with yellow as compared with the other two colours.

We were unable to identify any personality characteristics of those patients who showed the most or least response to colour.

Side-effects.-Of the 48 patients, 27 reported side-effects; drowsiness was the commonest, occurring in 17 patients. An analysis of all the patients with side-effects and a further analysis of those who complained only of drowsiness showed no association of the side-effects with any particular week of the trial, nor were side-effects significantly correlated with any particular colour. There was no sex difference as regards side-effects, though there was a slight preponderance of female patients who complained of drowsiness.

\section{Discussion}

The paucity of published data on the possible effects of tablet colour on the clinical response is somewhat surprising. Though inquiries to drug firms revealed considerable interest in this subject, they at the same time confirmed the lack of controlled studies designed to throw light on this aspect of treatment. This is perhaps because drug firms have concentrated so far in presenting drugs in an easily recognizable and distinctive form, hence the term "attractive," so commonly used in presentations of consumer goods and implying psychological preference, is rarely seen in the advertisements of medical drugs. On extensive search we found only one such study of analgesics in dental patients-that reported by Nagao et al. (1968).

Two interesting related studies of children's preferences between different-coloured tablets are described by Jolly and Forrest (1958) and Grainger (1958). The broader aspect of the relationship between colour and form in various stages of human development (Lindberg, 1938) and its association with personality features (Rorschach test) have also been the subject of investigation.

The results obtained with the two methods of assessment used in this study call for further comment particularly the close agreement between the physicians' ratings and the patients' self-ratings. Though it could be argued that the physicians' ratings were based largety on the verbal report of 
TABLE II.-Mean Scores on Self-rating Assessment in Relation to Colour

\begin{tabular}{|c|c|c|c|c|c|c|c|c|c|c|}
\hline \multicolumn{5}{|c|}{ Symptom Group } & \multirow{2}{*}{$\begin{array}{c}\begin{array}{c}\text { No. of } \\
\text { Patients }\end{array} \\
48 \\
48 \\
17 \\
28\end{array}$} & \multirow{2}{*}{\begin{tabular}{l|} 
Red \\
$3 \cdot 7$ \\
$3 \cdot 2$ \\
$3 \cdot 9$ \\
$4 \cdot 4$
\end{tabular}} & \multirow{2}{*}{$\begin{array}{c}\text { Yellow } \\
3.9 \\
3.3 \\
3.6 \\
3.6\end{array}$} & \multirow{2}{*}{$\begin{array}{c}\text { Green } \\
3 \cdot 6 \\
3 \cdot 1 \\
3 \cdot 2 \\
3 \cdot 8\end{array}$} & \multirow{2}{*}{ 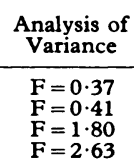 } & \multirow{2}{*}{$\begin{array}{c}\begin{array}{c}\text { Level of } \\
\text { Significance }\end{array} \\
\text { N.S. } \\
\text { N.S. } \\
\text { N.S. } \\
\text { N.S. }\end{array}$} \\
\hline $\begin{array}{l}\text { Psychic anxiety } \\
\text { Somatic symptoms } \\
\text { Phobias } \quad \ldots \\
\text { Depression } \quad .\end{array}$ & $\begin{array}{l}\ldots \\
\cdots \\
\cdots\end{array}$ & $\begin{array}{l}\ldots \\
\cdots \\
\cdots\end{array}$ & $\begin{array}{l}\ldots \\
\cdots \\
\cdots\end{array}$ & $\begin{array}{l}\ldots \\
\cdots \\
\cdots\end{array}$ & & & & & & \\
\hline
\end{tabular}

TABLE III.-Physicians' Assessment: Table of Mean Improvements

\begin{tabular}{|c|c|c|c|c|c|c|c|c|c|c|}
\hline \multicolumn{5}{|c|}{ Symptom Group } & \multirow{2}{*}{$\begin{array}{c}\begin{array}{c}\text { No. of } \\
\text { Patients }\end{array} \\
48 \\
48 \\
17 \\
32 \\
48\end{array}$} & \multirow{2}{*}{$\begin{array}{c}\begin{array}{c}1 \text { st } \\
\text { Week }\end{array} \\
1 \cdot 0 \\
0 \cdot 8 \\
1 \cdot 1 \\
0 \cdot 8 \\
1 \cdot 1\end{array}$} & \multirow{2}{*}{$\begin{array}{c}\begin{array}{c}\text { 2nd } \\
\text { Week }\end{array} \\
0.9 \\
0.8 \\
1.9 \\
0.9 \\
1.1\end{array}$} & \multirow{2}{*}{$\begin{array}{l}\begin{array}{c}3 \text { rd } \\
\text { Week }\end{array} \\
1 \cdot 1 \dagger \\
0.9 \dagger \\
1.2 * \\
1.1 \dagger \\
1.5 \dagger\end{array}$} & \multirow{2}{*}{$\begin{array}{c}\begin{array}{c}\text { Analysis of Variance } \\
\text { Between Weeks }\end{array} \\
F=0.24 \\
F=0.22 \\
F=0.58 \\
F=0.27 \\
F=0.99\end{array}$} & \multirow{2}{*}{$\begin{array}{c}\begin{array}{c}\text { Level of } \\
\text { Significance } \\
\text { Between Weeks }\end{array} \\
\text { N.S. } \\
\text { N.S. } \\
\text { N.S. } \\
\text { N.S. } \\
\text { N.S. }\end{array}$} \\
\hline $\begin{array}{l}\text { Psychic anxiety } \\
\text { Somatic symptoms } \\
\text { Phobias } \quad \ldots \\
\text { Depression . } \\
\text { Overall assessment }\end{array}$ & $\begin{array}{l}\cdots \\
\cdots \\
\cdots\end{array}$ & $\begin{array}{l}\ldots \\
\cdots \\
\cdots \\
\cdots\end{array}$ & $\begin{array}{l}\ldots \\
\cdots \\
\cdots \\
\cdots\end{array}$ & $\begin{array}{l}\ldots \\
\cdots \\
\cdots \\
\ldots\end{array}$ & & & & & & \\
\hline
\end{tabular}

Third week mean improvements have been tested for significance. They are all significantly greater than zero:
${ }_{\mathrm{P}}<0.01 ; \quad+\mathrm{P}<0.001$.

TABLE IV.-Physicians' Assessment in Relation to Colour

\begin{tabular}{|c|c|c|c|c|c|c|c|c|c|c|}
\hline \multicolumn{5}{|c|}{ Symptom Group } & \multirow{2}{*}{$\begin{array}{c}\begin{array}{c}\text { No. of } \\
\text { Patients }\end{array} \\
48 \\
48 \\
17 \\
32 \\
48\end{array}$} & \multirow{2}{*}{$\begin{array}{l}\text { Red } \\
1 \cdot 0 \\
0 \cdot 6 \\
0 \cdot 8 \\
0 \cdot 7 \\
1 \cdot 1\end{array}$} & \multirow{2}{*}{$\begin{array}{c}\text { Yellow } \\
1 \cdot 0 \\
0.7 \\
1.2 \\
1 \cdot 2 \\
1 \cdot 1\end{array}$} & \multirow{2}{*}{$\begin{array}{c}\text { Green } \\
1 \cdot 1 \\
1.2 \\
2.3 \\
0.8 \\
1.5\end{array}$} & \multirow{2}{*}{$\begin{array}{c}\begin{array}{c}\text { Analysis of } \\
\text { Variance }\end{array} \\
F=0.21 \\
F=2.86 \\
F=6.05 \\
F=1.17 \\
F=0.99\end{array}$} & \multirow{2}{*}{$\begin{array}{c}\begin{array}{c}\text { Level of } \\
\text { Significance }\end{array} \\
\text { N.S. } \\
\text { N.S. } \\
\text { P<0.01 } \\
\text { N.S. } \\
\text { N.S. }\end{array}$} \\
\hline $\begin{array}{l}\text { Psychic anxiety } \\
\text { Somatic symptoms } \\
\text { Phobias } \quad . . \\
\text { Depression . . } \\
\text { Overall assessment }\end{array}$ & $\begin{array}{l}\cdots \\
\cdots \\
\cdots\end{array}$ & $\begin{array}{l}\cdots \\
\cdots \\
\cdots \\
\cdots\end{array}$ & $\begin{array}{l}. \\
\cdots \\
\cdots\end{array}$ & $\begin{array}{l}\ldots \\
\cdots \\
\cdots \\
\cdots\end{array}$ & & & & & & \\
\hline
\end{tabular}

TABLE V.-Physicians' Assessment of Phobias (Analysis of Variance for Unequal Subclasses)

\begin{tabular}{|c|c|c|c|c|c|}
\hline Source of Variation & D.F. & $\begin{array}{l}\text { Sum of } \\
\text { Squares }\end{array}$ & $\begin{array}{l}\text { Mean } \\
\text { Scores }\end{array}$ & $\mathbf{F}$ & $\mathbf{P}$ \\
\hline $\begin{array}{l}\text { Test for colour: } \\
\text { Between periods } \\
\text { Colour (adjusted) } \\
\text { Periods and colour }\end{array}$ & $\begin{array}{l}2 \\
2 \\
4\end{array}$ & $\begin{array}{r}64.59 \\
140.44 \\
205.03\end{array}$ & $70 \cdot 22$ & $6 \cdot 05$ & $<0.01$ \\
\hline $\begin{array}{l}\text { Test for period: } \\
\text { Between colours ... } \\
\text { Periods (adjusted) } \\
\text { Periods and colour } \\
\text { Interaction } \\
\text { Residual .. }\end{array}$ & $\begin{array}{r}2 \\
2 \\
4 \\
4 \\
42\end{array}$ & $\begin{array}{r}191 \cdot 65 \\
13.38 \\
205 \cdot 03 \\
33.45 \\
487.53\end{array}$ & $\begin{array}{r}6 \cdot 69 \\
8 \cdot 36 \\
11 \cdot 61\end{array}$ & $\begin{array}{l}0.58 \\
0.72\end{array}$ & $\begin{array}{l}\text { N.S. } \\
\text { N.S. }\end{array}$ \\
\hline Total & 50 & $726 \cdot 00$ & & & \\
\hline
\end{tabular}

the patients' progress during the previous week, they reflected equally the physicians' critical appraisal of the patients' clinical state. The mean scores on the self-rating scales, on the other hand, were derived from the daily assessments made by the patients, and these might be regarded as providing a more accurate account of events during the previous week than the usual account given by the patients in a clinical interview, when only the symptoms which fluctuate most tend to be recalled and perhaps overemphasized.

As regards the patients' response to treatment, comparison between the mean scores of each period shows an overall beneficial therapeutic effect likely to be attributable to the drug rather than to any particular psychological effects, since this improvement did not significantly differ from week to week.

The mean scores both on the self-rating scales and on the physicians' assessments were found not to differ very much from week to week. This may be deceptive, since they represented a wide range of scores between individual patients, so that some patients were very anxious indeed, whereas anxiety symptoms in others were of a mild degree. There were significant differences between the scores of individual patients in each week. The effect of these between-patient differences is, of course, eliminated from the comparisons of colours and periods by the analysis of variance.

Though our results as regards colour show trends rather than significant differences, the consistent pattern in colour preferred on two separate methods of assessment cannot be ignored. This is particularly so since in a previous pilot study we also showed the same order of colour preferences. The unexpected finding that depressive symptoms respond best to yellow and not to green may reflect an essential psychological difference between anxiety and depressive symptoms, or may be a chance association.

Though our findings are based on a relatively small number of patients, the results of treatment of the neuroses are not such as to enable us to ignore any ancillary factor which might enhance the response of patients to drug treatment. Further investigations designed to evaluate the influence of colour in drug treatment would therefore seem to be justified.

We would like to thank Mr. H. H. Poole, Mr. W. T. Wing, and Mr. R. A. Lidgate, chief pharmacists at the Royal Victoria Infirmary, Newcastle General Hospital and Shotley Bridge General Hospital respectively, for their help in this study, and Mrs. D. Weightman for assistance with the statistical analysis. We also wish to thank John Wyeth \& Brother Ltd. for supplying the tablets.

\section{REFERENCES}

Beber, C. R. (1965). Diseases of the Nervous System, 26, 591.

Beecher, H. K. (1955). Fournal of the American Medical Association, 159, 1602.

Grainger, H. S. (1958). Pharmaceutical fournal, 180, 70.

Jolly, H., and Forrest T. R W (1958) Lancet, 1, 1308 .

Lader, M. H., and Wing, L. (1966). Physiological Measures, Sedative Drugs and Morbid Anxiety. London, Oxford University Press.

Le Gassicke, J., and McPherson, F. M. (1965). British fournal of Psychiatry, 111, 521.

Lindberg, B. J. (1938). Acta Psychiatrica et Neurologica, Suppl. No. 16.

Nagao, Y., Komiya, J., Kuroyanagi, K., Minaba, Y., and Susa, A. (1968). Shikwa Gakuho, 68, 139.

Rao, C. R. (1952). Advanced Statistical Methods in Biometric Research, Wiley, New York.

Shapiro, A. (1960). Behavioural Science, 5, 109. 